\title{
PROGRAM KEMITRAAN MASYARAKAT PENDAMPINGAN USAHA TELUR ASIN MANISE (MASIR, NIKMAT, SEHAT) SEBAGAI TELUR ASIN RENDAH KOLESTEROL DAN KAYA KALSIUM
}

\author{
Nikmatul Iza ${ }^{1}$, As'ad Syamsul Arifin ${ }^{2}$ \\ ${ }^{1,2)}$ IKIP Budi Utomo, Malang, Jawa Timur, Indonesia \\ 1*Email: nikmatuliza23.kendedes@gmail.com \\ ${ }^{2}$ Email: asad.ilem@yahoo.com
}

\begin{abstract}
Malang Regency is one of the districts in East Java which is famous for its food business. One of them is the salted egg business run by Mr. Musta'in which is located in Tamanharjo village, Singosari District, Malang Regency. Even though it has only been pioneered for \pm 5 years, the business has survived despite being limited to a family business with its own family members. The problem of the home business lies in how efforts must be made to improve the quality of production and nutritional value of salted eggs. The method used in this service is a survey and discussion of planned activities, improving the quality of salted egg production by procuring tools and conducting training and mentoring in the process of making salted eggs MANISE (Masir, Delicious, Healthy) the taste of onions to the packaging stage, increasing the nutritional value of salted eggs with testing cholesterol levels and calcium levels in salted egg products before and after treatment by adding garlic to the dough, and monitoring and evaluating activities. This service activity starts from February to September 2018. The results achieved through this community service program are the completion of several partner problems starting with taste, attractive packaging, and increasing the nutritional value of cracker products that have low levels of cholecolols and are rich in calcium. There are several activities that support the success of service programs such as training and mentoring in making onion flavored salted eggs, steaming, tapping and packaging processes, and can increase sales turnover in new products.
\end{abstract}

Keyword: salted egg, low cholesterol, rich in calsium, community partnership program.

\section{PENDAHULUAN}

Kabupaten Malang merupakan salah satu kabupaten di Jawa Timur yang terkenal dengan usaha makanan. Salah satunya adalah usaha telur asin yang dijalankan Pak Musta'in yang terletak di desa Tamanharjo, Kecamatan Singosari, Kabupaten Malang. Meskipun baru di rintis sejak \pm 5 tahunan usaha tersebut tetap bertahan meskipun sebatas usaha keluarga dengan karyawan anggota keluarganya sendiri, sedangkan usaha telur asin yang di jalankan warga yang lainnya sudah gulung tikar karena beberapa faktor, salah satunya adalah kurangnya modal. Beberapa faktor penghambat UKM yaitu (1) Kurangnya pemodalan, (2) Sumber
Daya Manusia (SDM) yang terbatas, (3) Lemahnya jaringan usaha dan kemampuan penetrasi pasar, (4) Terbatasnya sarana dan prasarana usaha, (5) Terbatasnya akses pasar (Hafsah, 2004).

Pengasinan merupakan salah satu upaya yang dilakukan untuk mengawetkan atau memperpanjang daya simpan telur bebek/itik, dapat mengurangi bau amis,memiliki cita rasa yang khas, dan dapat mempertahankan kualitas telur. Proses pengasinan telur yang umum dilakukan oleh masyarakat yaitu dengan menggunakan garam dapur sebagai bahan pengawetnya. Garam merupakan faktor utama dalam proses pengasinan telur yang bergunauntuk mencegah pembusukan telur (Novia dkk, 
2011). Menurut Puspitasari, dkk (2014), pada umumnya garam yang digunakan masyarakat adalah garam Natrium klorida $(\mathrm{NaCl} /$ garam dapur).Namun demikian terdapat beberapa permasalahan usaha rumahan telur asin milik Pak Musta'in yaitu rasa telur asin cenderung monoton dan tidak stabil dalam tiap produksi (kadang terlalu asin) dan sedikit basah, tidak ada kemasan pada telur asin, dan telur asin yang mengalami keretakan atau pecah, hanya diberi isolasi saja, yang membuat daya simpan telur asin tidak tahan lama, masih minimnya pengetahuan tentang gizi telur asin, sehingga diperlukan upaya untuk meningkatkan mutu hasil produksi dan untukmeningkatkan nilai gizi telur asin sehingga dapat meningkatkan daya saing penjualan dan otomatis akan meningkatkan pula pendapatan usaha, dan hal ini tentu akan berbanding lurus dengan peningkatan dan perbaikan perekonomian serta kesejahteraan karyawan.

Melalui Program pengabdian Kepada Masyarakat khususnya Program Kemitraan Masyarakat (PKM) ini, pengusul akan memberikan solusi dari permasalahan mitra dengan cara yaitu melakukan perbaikan mutu produksi telur asin dari segi tampilan rasa dan dalam bentuk kemasan. Dari segi nilai gizi, adonan telur asin ditambahkan bawang putih yang diduga dapat menurunkan kadar kolesterol. Kebutuhan kolesterol per/hari yaitu sebesar $1.100 \mathrm{mg}$, sedangkan kandungan kolesterol pada telur asin sebesar $2.118 \mathrm{mg} / 100$ gram. Diharapkan dengan pemberian perlakuan menggunakan bawang putih, maka kandungan kolesterol akan turun dan dapat menambah cita rasa yang nikmat untuk dikonsumsi, serta menyehatkan (Firdaus dkk, 2014).

\section{METODE PELAKSANAAN}

Metode yang digunakan dalam Program Kemitraan Masyarakat (PKM) ini terdiri dari beberapa tahap kegiatanantara lain(1) Survey dan diskusi rencana kegiatan (2) Peningkatan mutu produksi telur asin dengan pengadaan alat dan melakukan pelatihan dan pendampingan tentang proses pembuatan telur asin MANISE rasa bawang, proses pengukusan, pengetokan, dan pengemasan (3) Peningkatan nilai gizi telur asin dengan melakukan pengujian kadar kolesterol di laboratorium Sukofindo Jakarta dan pengujian kadar kalsium di laboratorium Kimia FMIPA UB pada produk telur asin sebelum perlakuan dan setelah perlakuan dengan penambahan bawang putih pada adonan (4) Tahap monitoring dan evaluasi kegiatan.Pengabdian dilakukan selama \pm 8 bulan mulai bula Februari sampai September 2018.

Adapun tahapan dalam proses pembuatan telur asin rasa bawang dapat dilihat pada Gambar 1.

\section{HASIL DAN PEMBAHASAN}

\section{A. Hasil Pengabdian Kepada Masyarakat}

Hasil yang telah dicapai dalam program pengabdian kepada masyarakat (PKM) dengan kegiatan pendampingan usaha telur asin MANISE (Masir, Nikmat, Sehat) sebagai berikut:

\section{Survey dan diskusi rencana kegiatan, pelatihan, dan pendampingan.}

Survey dan diskusi bertujuan untuk bertukar pikiran, sharing, dan mendapatkan saran dan masukan, serta agar komunikasi dengan mitra dapat berjalan dengan baik dan lancar. Kegiatan dirancang dan membahas tentang kegiatan yang akan dilakukan selama \pm 8 bulan ke depan. Kegiatan survey dapat dilihat pada Gambar 2.

\section{Peningkatan Mutu Produksi Telur Asin}

a. Penyerahan Peralatan Penunjang

Kegiatan penyerahan peralatan penunjang dilakukan dengan disaksikan secara langsung oleh Ketua RT 01 Pak Ali dan Ketua RW 04 Pak Suyono Desa Tamanharjo, sekaligus penandatangan serah terima peralatan. Peralatan penunjang yang diserahkan kepada mitra terdiri daridandang besar 501 unit dengan merk "Global Eagle Durable Ware"; Bahan dasar besi/baja; Diameter $60 \mathrm{~cm}$, tanggok jumbo sebanyak 5 unit, sabut cuci Merk "Honaga Kitchen Cleaner T-30, gayung Merk "Taiwan 
Plastics GY-02L, bak 28 memble sap Merk dan egg tray mika. Adapun gambar "SAP indocipta produk sebanyak 4 unit, penyerahan peralatan penunjang tampak pada blender 1 unit Merk "Miyako BL 101 PL, Gambar 3.

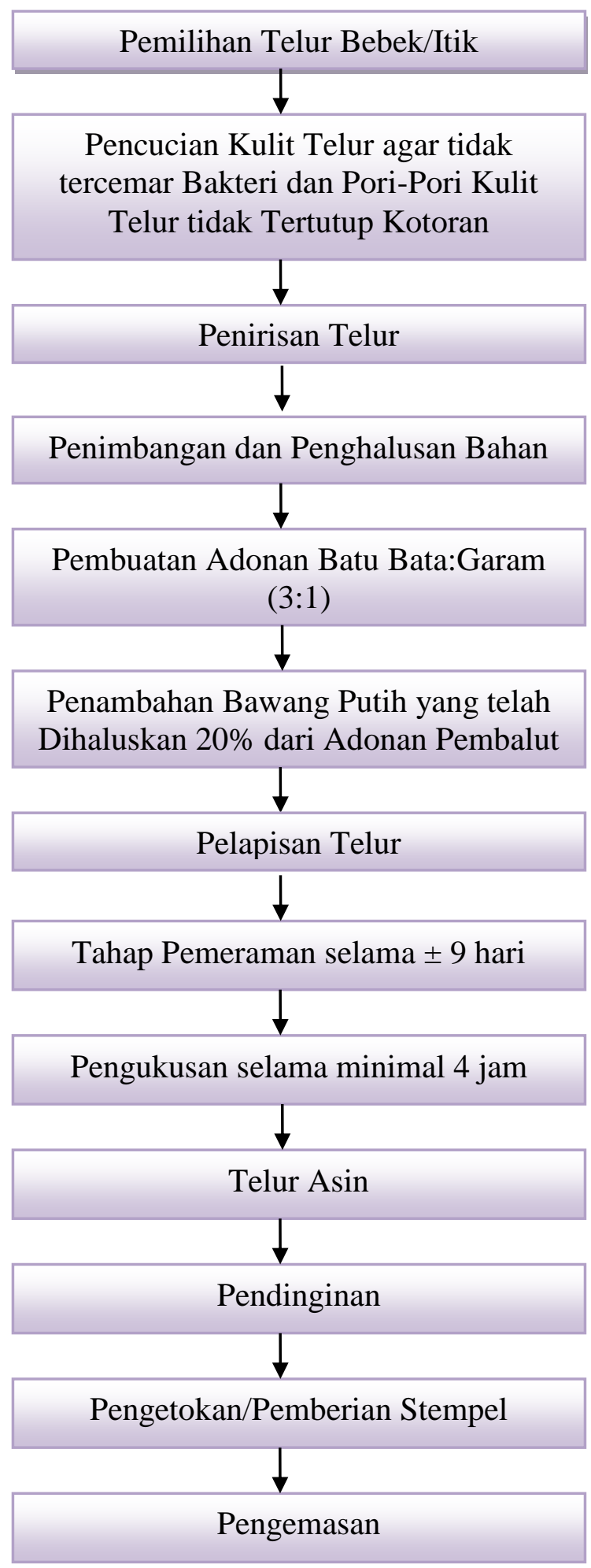

\section{Gambar 1. Proses Pembuatan Telur Asin Rasa Bawang}

b. Pelatihan dan Pendampingan Telur Asin MANISE Rasa Bawang
Pada tahap ini dilakukan pelatihan dan pendampingan teknik pembuatan telur asin produk baru yaitu rasa bawang yang 
dilaksanakan pada bulan April 2018 yang kegiatannya tampak pada Gambar 4.

Tahapan dalam proses pembuatan telur asin meliputi pemilihan telur bebek/itik yang memiliki kualitas yang baik, selanjutnya tahap pencucian dan penggosokan kulit telur dengan sabut cuci stainless supaya tidak tercemar bakteri dan pori-pori kulit telur tidak tertutup kotoran, tahap ini sangat penting karena menentukan kualitas telur asin.

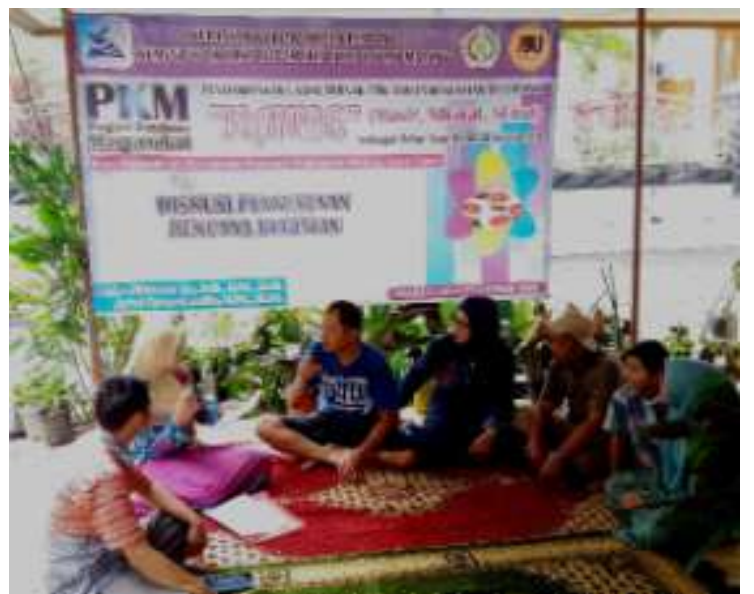

Gambar 2. Survey dan Diskusi Penyusunan Rencana Kegiatan (Sumber: doc. Pribadi, 2018)

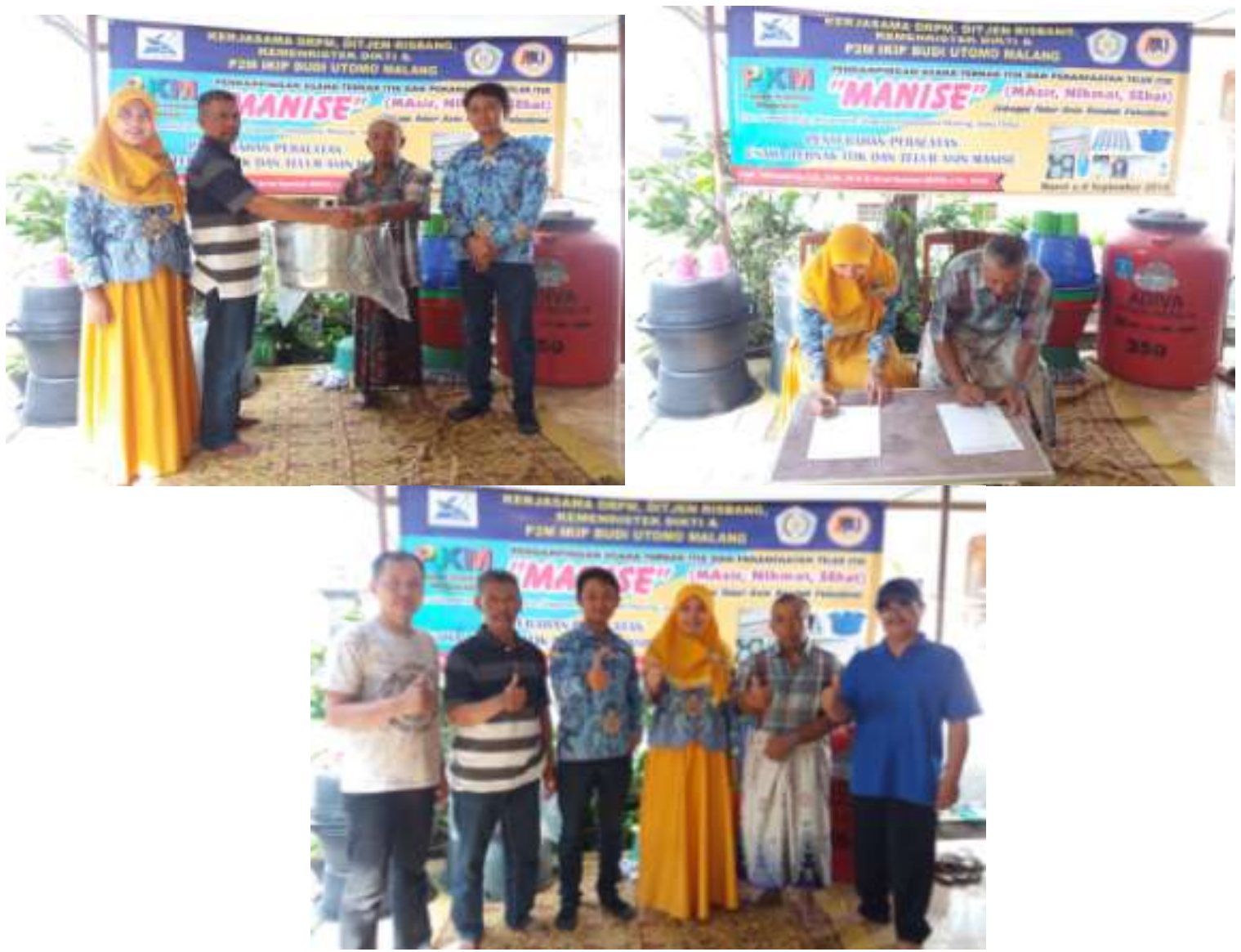

Gambar 3. Penyerahan Peralatan Penunjang (Sumber: doc. Pribadi, 2018)

Telur yang sudah di cucui bersih ditiriskan, kemudian dilakukan penimbangan dan penghalusan bahan, pembuatan adonan batu bata:garam dengan perbandingan 3:1, 
penambahan bawang putih yang telah dihaluskan 20\% dari adonan pembalut, pelapisan telur dengan adonan, dan tahap pemeraman selama \pm 9 hari. Pada tahap pemeraman, setiap bak pengasinan diberikan catatan waktu mulai pengasinan sampai siap di panen.

Telur asin yang memiliki kualitas yang baik yaitu yang memiliki rasa asin yang cukup (pemeraman dilakukan selama 7-10 hari) dan memiliki kuning telur yang berwarna kemerah-merahan dan terkesan berpasir/masir (Nurrahmawati, 2011) dan putih telurnya tidak terlalu asin (Sabar dkk, 2015).
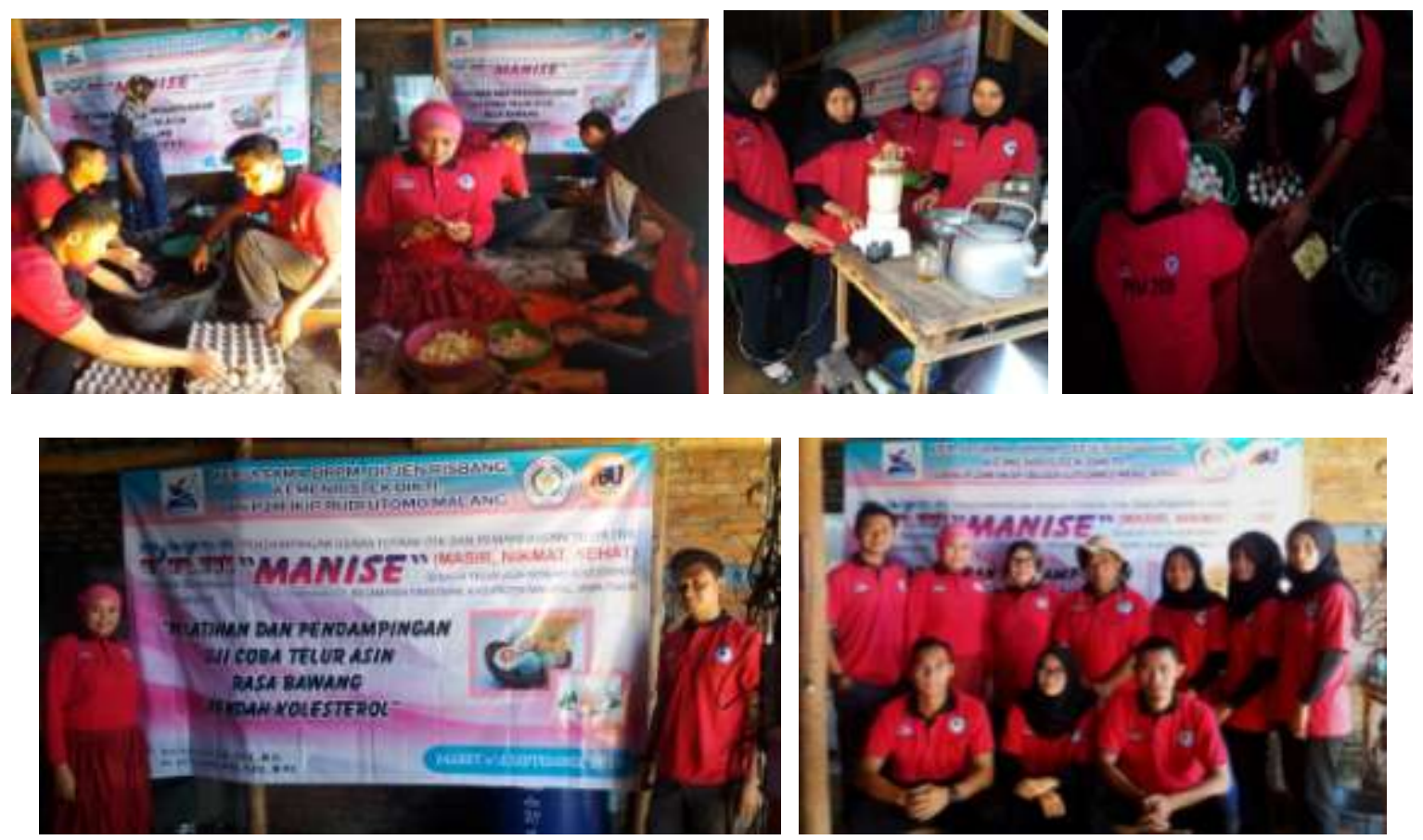

Gambar 4. Pelatihan dan Pendampingan Telur Asin Rasa Bawang (Sumber: doc. Pribadi, 2018)

Perbandingan kadar tanah:garam yaitu 3:1 dan bawang putih sebanyak $20 \%$ dari adonan pembalut yaitu $80 \mathrm{~g}$ per 1 butir telur. Proses pengasinan memiliki beberapa keuntungan antara lain mudah dilakukan, praktis, biayanya murah, serta dapat meningkatkan kesukaan konsumen apalagi dengan variasi baru telur asin rasa bawang (Agustina dkk, 2015).

c. Proses Pengukusan, Pengetokan/

Stempel, dan Pengemasan Telur Asin

Rasa Bawang.

Pada tahap ini dilakukan setelah tahap pemeraman selama \pm 9 hari, dilakukan proses pembersihan telur asin dari balutan campuran batu bata+garam+bawang, setelah telur asin bersih dilakukan proses pengukusan selama minimal 4 jam sehingga telur asin bisa tahan lebih lama dan yang menarik dari pengukusan telur asin dilakukan dengan menggunakan tungku kayu bakar sehingga menghasilkan aroma yang khas. Pada tahap ini tidak dilakukan proses perebusan karena dengan perebusan air dapat masuk ke dalam pori-pori telur, sehingga telur asin yang dihasilkan akan terkesan basah.

Tahap selanjutnya yaitu pendinginan telur asin dan dilakukan tahap pengetokan atau pemberian stempel yang menunjukkan ciri khas telur asin, serta pengemasan dengan menempelkan stiker atau desain kemasan dengan merek yang unik agar telihat lebih menarik perhatian konsumen. Rata-rata pengusaha telur asin lebih memilih mengemas produk telurnya dengan kemasan kertas karton atau terbuka, setelah proses pengemasan telur asin siap untuk dipasarkan. Adapun proses pengukusan, pengetokan, dan 
pengemasan telur asin terlihat pada Gambar 5.

\section{Pengujian Kadar Kolesterol dan Kadar Kalsium}

Tahap pengujian telur asin dilakukan setelah telur asin dalam keadaan dingin setelah tahap pengukusan. Langkah pertama yang dilakukan yaitu penimbangan berat telur asin original dan telur asin rasa bawang sesuai dengan permintaan masing-masing laboratorium. Pengujian telur asin dilakukan di 2 laboratorium yang berbeda yaitu: (1) Uji kolesterol dilakukan di laboratorium Sukofindo Jakarta; (2) Uji Kalsium dilakukan di laboratorium pengujian mutu dan keamanan pangan THP Universitas Brawijaya. Uji kolesterol dan uji kalsium dilaksanakan pada 18 April 2018.
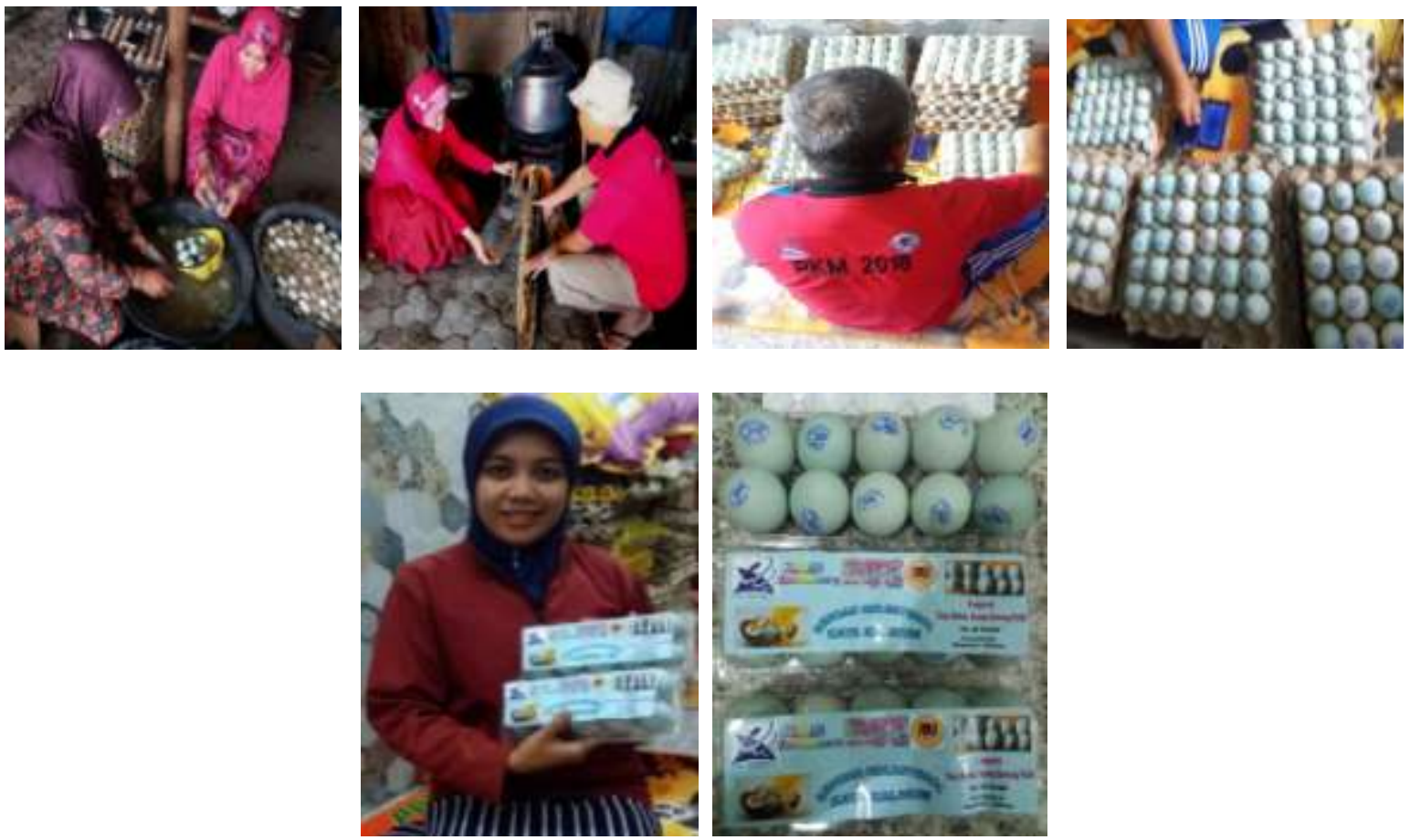

Gambar 5. Proses Pembersihan balutan,Pengukusan, Pengetokan, dan Pengemasan Telur Asin (Sumber: doc. Pribadi, 2018)

Adapun hasil dari masing-masung uji dapat dilihat pada Tabel 1 dan 2. Pada Tabel 1 tampak bahwa kadar kolesterol telur asin rasa bawang lebih rendah dibandingkan telur asin original. Penggunaan dan pemilihan bawang putih (Allium sativum L) merupakan salah satu jenis bawang-bawangan yang sudah lazim digunakan untuk menurunkan kadar kolesterol, apalagi telur asin yang diberi perlakuan bawang putih diharapkan akan terjadi penurunan kolesterol (Irawan, dkk., 2012).
Bawang putih sangat populer di masyarakat dan telah ditunjukkan melalui laporan medis dapat menurunkan tingkat Low Density Lipoprotein (LDL). Studi menunjukkan bahwa bawang putih dapat mengurangi kolesterol dan triglycerides 2 sampai $15 \%$. Penelitian yang dilakukan terhadap orang-orang yang diberi 800 miligrams (sekitar satu sendok) bawang putih setiap hari, mengalami penurunan tingkat kolesterol serta menurunkan kadar kolesterol (Irawan dkk, 2012).

Tabel 1. Uji Kolesterol Telur Asin

\begin{tabular}{cccc}
\hline Kode & Unit & Hasil Tes & Metode \\
\hline Original & $\%$ & 0,66 & $\mathrm{PO} / \mathrm{MM} / 27$ \\
Rasa Bawang & $\%$ & 0,51 & $\mathrm{PO} / \mathrm{MM} / 27$ \\
\hline
\end{tabular}


Hasil dari uji kalsium terlihat bahwa telur asin rasa bawang memiliki kadar kalsium yang tinggi (tabel 2) yaitu memiliki kadar kalsium 605,91 \pm 4,66 mg/kg dibandingkan dengan kadar kalsium pada telur asin original $165,81 \pm 0,11 \mathrm{mg} / \mathrm{kg}$. Bawang putih (Allium sativum $\mathrm{L}$ ) merupakan salah satu tumbuhan berumpun yang bersiung-siung yang terbungkus kulit tipis.

Tabel 2. Uji Kalsium Telur Asin

\begin{tabular}{ccccc}
\hline Kode & \multicolumn{2}{c}{ Hasil Analisis } & \multicolumn{2}{c}{ Metode Analisis } \\
\cline { 2 - 5 } Original & Kadar & Satuan & Pereaksi & Metode \\
Rasa Bawang & $165,81 \pm 0,11$ & $\mathrm{mg} / \mathrm{kg}$ & $\mathrm{HNO}_{3}$ & AAS \\
\hline
\end{tabular}

\section{Monitoring dan Evaluasi Kegiatan}

Kegiatan ini dimaksudkan untuk memonitoring kegiatan yang telah dilakukan mitra. Pada kegiatan ini lebih terfokus untuk berdiskusi, berbagi pendapat, dan pengalaman mitra, serta melihat keberlanjutan program PKM yang terlihat
Kandungan zat gizi yang terdapat dalam umbi lapis ini antara lain protein, lemak, kalsium, fosfor, besi, Vitamin A, Vitamin B1, dan Vitamin C yang berkhasiat sebagai, antikoagulan, antiseptik, aantihistamin, dan bakteriostatik (Irawan dkk, 2012). Jadi jelas telur asin rasa bawang MANISE selain nikmat juga menyehatkan.

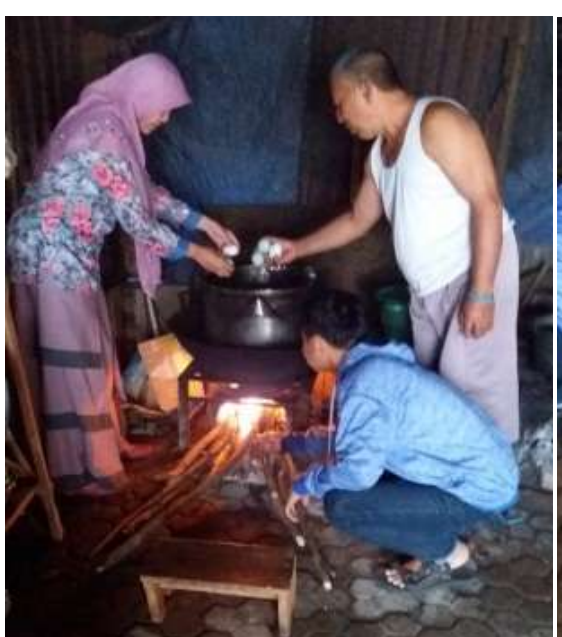

Gambar 6. Monitoring dan Evaluasi Keberlanjutan Usaha

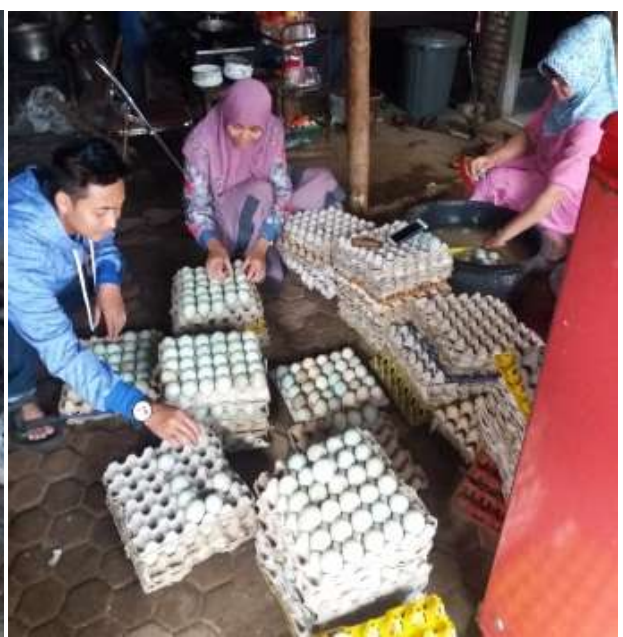

\section{KESIMPULAN}

Adapun kesimpulan dari Program Kemitraan Masyarakat (PKM) ini yaitu

1. Peningkatan mutu produksi dalam hal tampilan telah berhasil dilakukan dengan adanya penambahan bawang menjadikan produk baru telur asin MANISE (Masir, Nikmat, Sehat)rasa bawang melalui prosedur pembuatan telur asin dengan tahapan dan takaran yang benar. Pada pengabdian ini juga ditambahkan pada gambar 5. Berdasarkan hasil monitoring dengan adanya variasi baru pada telur asin secara otmatis dapat meningkatkan omzet penjualan. Monitoring dan evaluasi keberlanjutan usah dapat dilihat pada Gambar 6 berikut.

kemasan dan stiker agar tampilan menjadi semakin menarik.

2. Peningkatan nilai gizi telur asin varian baru yaitu dengan melakukan uji kolesterol danuji kalsiumdengan melakukan modifikasi telur asin rasa bawang. Hal ini ditunjukkan dengan data hasil analisis kandungan gizi pada telur asin original dan telur asin rasa bawang. Data menunjukkan bahwa telur asin rasa bawang memiliki kualitas gizi yang lebih 
baik dibandingkan dengan telur asin original.

\section{REFERENSI}

Hafsah, M. J., 2004, Upaya Pengembangan Usaha Kecil danMenengah (UKM), Jurnal Infokop, No 25, 40-44.

Novia, D., S. Melia dan N. Z. Ayuza, 2011, Kajian Suhu Pengovenan Terhadap Kadar Protein dan NilaiOrganoleptik Telur Asin. Jurnal Peternakan, No. 2, Vol.8, 70-76, :https://media.neliti.com/ media/publications/125903-ID-kajiansuhu-pengovenan-terhadap-kadarpr.pdf.

Puspitasari, C., D., Rachmawanti dan Siswanti, 2014, Pengaruh Kombinasi Media dan Konsentrasi IodiumPada Dua Jenis Garam (Nacl Dan Kcl) Terhadap Kadar Iodium dan Kualitas Sensoris Telur Asin.Jurnal Teknosains Panga, No. 4, Vol. 3, 1-7, :https://jurnal.uns.ac.id.

Firdaus, F. Z., Alfian, R., Sya'roni, M. I., 2014,Telur EMAS (Enak, Masir, Aman,Sehat) sebagai Telur Asin Rendah Kolesterol, PKM: UB.:(https://media.neliti.com/media/pu blications/169564-ID-telur-emas-enakmasir-aman-sehat-sebagai.pdf.

Nurrahmawati, K., 2011, Uji Protein dan Kalsium pada Telur Asin HasilPengasinan Menggunakan Abu Pelepah Kelapa dan Perendaman dalam Larutan Teh Berbagai Konsentrasi, Skripsi tidak diterbitkan, IAINWalisongo: Semarang.

Sabar, W. P \& Parnanto, N. H. R., 2015, Peningkatan Usaha Telur Asin Asap,Jurnal Ivovasi dan Kewirausahaan, No. 2, Voi. 4, 87-93. http://download.portalgaruda.org/articl e.php? article $=360744 \&$ val $=8163 \&$ title $=$ PENINGKATAN\%20USAHA\%20T ELUR\%20ASIN\%20ASAP

Agustina, K. K., Dharmayudha, A. A. G. O., Swacita, I. B. N., Sudimartini, L. M., 2015. Analisis Nilai Gizi Telur Asin yang Dibuat dengan Media Kulit $\mathrm{BuAH}$ Manggis selama Masa
Pemeraman. Buletin Veteriner Udayana, No. 2, Vol. 2, 121-128. https://www.researchgate.net/publicatio n/319138989_PEMANFAATAN_KUL IT_BAUAH_MANGGIS_SEBAGAI MEDIA_PEMBUATAN_TELUR_ASI N/fulltext/59943a020f7e9b98953ae742 1319138989_PEMANFAATAN_KULI T_BAUAH_MANGGIS_SEBAGAI MEDIA_PEMBUATAN_TELUR_ASI N.pdf?origin=publication_detail.

Irawan, B \& Septiana, M., 2012, Efek Komposisi Tanah dan Biofarmaka terhadap Penurunan Kadar Kolesterol pada Pengasinan Telur Itik Albino. Agroscientiae, No. 2, Vol. 19, 122-127. :http://download.portalgaruda.org/art icle.php? article $=96331 \& \mathrm{val}=2295$. 